\title{
RAPID DIAGNOSIS OF RUBELLA BY DIRECT IMMUNO- FLUORESCENT STAINING OF DESQUAMATED CELLS IN THROAT SWABS
}

\author{
Margaret Haire and Diana S. M. Hadden \\ Department of Microbiology, The Queen's University of Belfast
}

RUBELLA in children can be diagnosed during the acute stage of the illness by direct immunofluorescent staining of virus antigen in infected cells from the throat (Haire, 1969a). To evaluate the method, a further study was made in a larger number of patients of different ages. Clinical findings were carefully assessed.

\section{MATERIALS AND METHODS}

Patients. Throat swabs and sera were obtained in the 1 st wk of illness from 76 patients who were apparently suffering from German measles, during an epidemic. The patients were visited in their homes and observed clinically by one or other of two doctors who then took throat swabs and serum specimens. Only one throat swab was taken from most of the patients, but additional swabs were collected from 15 of the 28 patients over 12 yr of age at later visits, all within the 1st wk after the appearance of the rash; a further swab was taken from one patient 10 days after onset when she complained of a sore throat. Second serum specimens were collected during convalescence. All the laboratory tests were done by one person.

Diagnosis by direct immunofluorescence. Preparations for detection of virus antigen by direct immunofluorescence were made by swirling each throat swab in $4 \mathrm{ml}$ of $0.01 \mathrm{~m}$ phosphatebuffered saline to remove the cells, and then spinning the fluid at 800 r.p.m. for $5 \mathrm{~min}$. The deposited cells were re-washed with a further $4 \mathrm{ml}$ of buffer and, after decanting most of the supernatant, were finally resuspended in $0.5 \mathrm{ml}$ of buffer at the bottom of the tube. Four drops of this cell suspension were placed on each of four slides and, when dry, they were fixed for $10 \mathrm{~min}$. in fresh acetone. All preparations were stained with the following globulins conjugated with fluorescein isothiocyanate (FITC) (Sigma Chemical Company): rubellaimmune hamster globulin, non-immune hamster globulin, rubella-immune rabbit globulin and non-immune rabbit globulin. The rubella-immune sera were obtained from hamsters bearing virus-infected tumours (Haire, 1969b) and from rabbits inoculated with rubella virus grown in RK13 cells. Herpes simplex-immune guinea-pig globulin, non-immune guinea-pig globulin and mumps-immune rabbit globulin-fluorescein conjugates were also used as controls (Haire, 1969a). All conjugates had been adsorbed with human liver powder. After staining, slides were dipped in 1 in 150,000 Evans blue and mounted in glycerol-saline, $p \mathrm{H} 8 \cdot 3$. In positive cases both the hamster and the rabbit conjugates were equally satisfactory, though the staining produced by the former was more intense. The slides made from the throat swabs were coded and, when it was not possible to stain them immediately, they were stored at $-70^{\circ} \mathrm{C}$ in the presence of silica gel.

Virus isolation. Virus was isolated on RK13 cells and identified by immunofluorescence (Schmidt et al., 1966; Gispen and Brand-Saathof, 1967).

Serological diagnosis. Patients' sera were stored at $-20^{\circ} \mathrm{C}$ until tested. They were examined for haemagglutination-inhibiting (HI) antibodies with rubella haemagglutinin purchased from Flow Laboratories, Ltd. Some sera were tested by indirect immunofluorescence for rubella-specific IgM antibody (Haire and Hadden, 1970); coverslip preparations

Received 3 Sept. 1971; accepted 27 Sept. 1971.

J. MED. MICROBIOL.—VOL. 5 (1972) 
of rubella-infected BHK21 cells were treated first with the patient's serum and then, after washing, with anti-human IgM conjugated with FITC (Wellcome Reagents, Ltd).

\section{RESUlts}

Serological diagnosis of rubella was made in 63 of the 76 patients by finding a four-fold or greater rise in rubella $\mathrm{HI}$ antibodies. Thirty-five of the 63 patients were aged 0-12 yr, 13 were aged 12-17 yr and 15 were over 18 yr old.

Diagnosis was confirmed by direct immunofluorescence in 34 of the 63 patients (53.9 per cent.) and virus was isolated from 39 patients (61.9 per cent.)

TABLE I

Comparison of the direct immunofluorescence test with virus isolation for the diagnosis of rubella in patients of various ages

\begin{tabular}{l|c|c|c}
\hline & \multicolumn{2}{|c}{ Number of patients in the age range stated } \\
\cline { 2 - 3 } Age (yr) & \multicolumn{2}{|c|}{ who were diagnosed by } & \\
\cline { 2 - 3 } & $\begin{array}{c}\text { direct } \\
\text { who were } \\
\text { examined }\end{array}$ & $\begin{array}{c}\text { virus } \\
\text { isolation }\end{array}$ & \\
\hline $0-5$ & immunofluorescence & 7 & 12 \\
$6-11$ & 5 & 13 & 23 \\
$12-17$ & 15 & 13 \\
18 and over & 6 & 10 & 15 \\
\hline Any & 3 & 39 & 63 \\
\hline
\end{tabular}

(table I). Both methods were positive in 21 patients, and both were negative in 11 patients. Direct immunofluorescence and virus isolation were equally sensitive in patients under $12 \mathrm{yr}$ of age (each was positive in $57 \cdot 1$ per cent. of cases), but more of the older patients were diagnosed by virus isolation ( $67.8 \mathrm{per}$ cent., as compared with 50 per cent. by direct immunofluorescence). The inclusion of the results from the additional swabs taken from the older patients did not alter this latter difference. In all, 22 of 56 swabs (39.3 per cent.) obtained from 15 patients over 12 yr of age were positive by direct immunofluorescence, and 34 of 51 swabs (66.7 per cent.) from the same patients were positive by virus isolation. Rubella virus was isolated from the swab taken from one patient 10 days after onset.

The clinical records showed that 31 of the 34 patients who were diagnosed by direct immunofluorescence had a well-defined rash and only three had a faint rash at the time of taking the first positive throat swab (table II). On the other hand, ten of the 29 patients who were not diagnosed by immunofluorescence had a faint rash at the time when specimens were taken. The association between faintness of the rash and negative diagnosis by immunofluorescence is significant 
$\left(\chi^{2}=4 \cdot 8\right.$, d.f. I, $\left.0.05>P>0 \cdot 02\right)$. Seven of the 39 patients from whom virus was isolated had a faint rash when the first positive throat swab was taken, while five of the 24 patients from whom virus was not isolated had a faint rash. Failure to isolate virus did not seem to be related significantly to the faintness of the rash $\left(\chi^{2}=0.04489\right.$, d.f. I, $\left.0.9>\mathrm{P}>0.8\right)$.

The importance of enlarged post-auricular glands in clinical diagnosis is confirmed by finding this sign in 56 of the 63 proven cases of rubella; these

\section{TABLE II}

Results of direct immunofluorescence and virus isolation tests for the diagnosis of rubella at various times after the appearance of the rash, and their relation to the intensity of the rash

\begin{tabular}{|c|c|c|c|c|}
\hline \multirow{3}{*}{$\begin{array}{c}\text { Days after } \\
\text { appearance } \\
\text { of rash* }\end{array}$} & \multicolumn{4}{|c|}{$\begin{array}{l}\text { Number of patients, examined on the day stated, } \\
\text { in whom diagnosis by }\end{array}$} \\
\hline & \multicolumn{2}{|c|}{$\begin{array}{l}\text { direct immunofluorescence } \\
\text { was }\end{array}$} & \multicolumn{2}{|c|}{$\begin{array}{l}\text { virus isolation } \\
\text { was }\end{array}$} \\
\hline & positive & negative & positive & negative \\
\hline $\begin{array}{l}0 \dagger \\
1 \\
2 \\
3 \\
4 \\
5 \\
6\end{array}$ & $\begin{array}{l}2 \\
11(2) \div \\
11 \\
5 \\
4(1) \\
0 \\
1\end{array}$ & $\begin{array}{l}6 \\
7 \\
9(2) \\
9(4) \\
3(2) \\
3(2) \\
1 \\
\cdots\end{array}$ & $\begin{array}{r}5 \\
14(2) \\
9(2) \\
5(2) \\
4(1) \\
2 \\
\ldots\end{array}$ & $\begin{array}{rr}3 & \\
9 & (2) \\
10 & (2) \\
1 & \\
1 & (1) \\
\ldots & \\
\ldots & \end{array}$ \\
\hline Any & 34 & 29 & 39 & 24 \\
\hline
\end{tabular}

* Day on which positive or negative diagnosis was first made; specimens were collected from 15 of the older patients on several successive days.

+ Day of appearance of the rash.

¥ In parentheses: number of patients with only a faint rash.

glands were palpable in 31 of the 34 patients diagnosed by immunofluorescence and in 36 of the 39 patients from whom virus was isolated.

Four of the 13 patients who failed to show a rise in the titre of rubella HI antibody during the observed course of illness were diagnosed as rubella by other methods, namely, two by means of the indirect immunofluorescence test for rubella-specific IgM antibody in the serum, one by virus isolation and one by direct immunofluorescence of infected cells from the throat. This last patient had definite clinical signs of infection and was also a close contact of a proven case of rubella; his initial serum sample had been taken too late to allow diagnosis by the HI test. Two other patients were diagnosed respectively as Paul-Bunnell-positive glandular fever and drug rash. Seven patients could not be diagnosed; four had urticarial rashes without obvious cause. 


\section{DISCUSSION}

We reported previously the demonstration of rubella virus antigen in cells from throat swabs in 11 of 12 patients aged $10 \mathrm{yr}$ or less (Haire, 1969a). We have now shown that diagnosis by direct immunofluorescence can be made in older patients. However, the rate of diagnosis was lower in the present than in the earlier study, even in the younger patients. One explanation for this may be that better throat swabs were taken in the earlier study, in which the doctor taking the specimens had an assistant, and five of the children were in hospital. In the present study, all the patients were at home and the two doctors who took the specimens were unaided. They formed the opinion that taking a satisfactory throat swab was quite disturbing to the patient, even more so than venepuncture. For this reason it was not possible to organise a proper serial study in individual patients of the sensitivity of the direct immunofluorescent diagnostic method in relation to the time of taking the swab. Swabs were taken during the 1st wk after the appearance of the rash and generally showed the presence of virus antigen. A swab taken on the 10th day from one patient was still positive by virus isolation; other patients were not swabbed later than the 1st wk after the appearance of the rash because they were well clinically by this time.

The greater sensitivity of the direct immunofluorescent method in children under $12 \mathrm{yr}$ of age may be due to a more florid type of infection in the younger patients. Thus, we have found that swabs from younger patients are more satisfactory for immunofluorescent studies because they contain more cells. Moreover, our results indicate that diagnosis by direct immunofluorescence is more reliable when the rash is marked, presumably because more viruscontaining cells are shed from the tonsils and pharynx at this time.

A rapid laboratory diagnosis of rubella illness is often required, particularly in pregnancy. The HI antibody test is reliable, but paired serum specimens are needed and the acute serum specimen should be taken within $48 \mathrm{hr}$ of the onset of symptoms. Virus isolation and identification is tedious and may take $3 \mathrm{wk}$ or longer. Direct immunofluorescence can provide an answer within $24 \mathrm{hr}$ and can therefore be of real help to the physician in the management of the case.

\section{SUMMARY}

Diagnosis of rubella by direct immunofluorescent staining of infected cells from throat swabs was studied in children and adults and compared with virus isolation. Under $12 \mathrm{yr}$ of age both methods are equally sensitive, while in older patients virus isolation is the more sensitive. Since the immunofluorescence technique takes less than $24 \mathrm{hr}$ to perform and virus isolation may take $3 \mathrm{wk}$ or longer, the former method has obvious advantages in the rapid diagnosis of rubella.

We wish to thank the patients and their doctors for their co-operation. Dr Florence Curran helped in obtaining specimens, and Mr John Russell and Miss Anne J. Fulton gave technical assistance. Professor K. B. Fraser gave valuable advice.

This work was supported by a grant from the National Fund for Research into Crippling Diseases. 


\section{REFERENCES}

GisPen, R., AND BRAND-SAATHoF, B. 1967. Assay of rubella antibodies by immunofluorescence, complement fixation and neutralization. Arch. ges. Virusforsch., $21,334$.

HAIRE, MARGARET 1969a. Rapid identification of rubella-virus antigen from throat swabs. Lancet, 1, 920.

Haire, Margaret 1969b. Production of rubella antiserum in hamsters. J. Med. Microbiol., 2, 376.

Haire, Margaret, ANd Hadden, Diana, S. M. 1970. Immunoglobulin responses in rubella and its complications. Br. Med.J., 3, 130.

Schmidt, Nathalie J., LenNette, E. H., Woodie, J. D., and Ho, Helen H. 1966. Identification of rubella virus isolates by immunofluorescent staining, and a comparison of the sensitivity of three cell culture systems for recovery of virus. J. Lab. Clin. Med., 68, 502. 